\title{
6. Evidence on school choice and the human right to education
}

\section{Joanna Härmä}

\section{INTRODUCTION}

"An uneducated person is no different from a beast", or such was the opinion of a father of a primary school child in a rural village in Uttar Pradesh over a decade ago. ${ }^{1}$ This father was intent on claiming the right to an education for his child but felt unable to rely on the free government school system. Rather, he was pressed by circumstances (government teachers who simply did no teaching) to "choose" a private school instead. This situation is lauded by some, such as James Tooley (2009) as positive school choice, but actually, like many of his peers, the father wished for a well-functioning government school instead that would obviate the need for any "choice" at all (Härmä, 2008). Education is virtually universally considered a fundamental human right due to its intrinsic and instrumental value. It is crucially important to all aspects of life, including defending one's own human rights. Education can empower and formal schooling, where children from various backgrounds come together to learn, can help to forge social cohesion, can build positive group identities, and can increase awareness of and respect for diversity within society.

However, at the same time, education can be misused as an instrument of suppression of weaker groups, minorities, and the socially and economically disadvantaged. Because of this, international human rights law recognizes the liberty of parents to choose schools other than mainstream government ones for their children, in particular to conform with their religious and philosophical convictions, as well as different

1

Focus group respondent during data collection for my doctoral study in 2008 
linguistic needs (Zinigrad, Chapter 4, this volume). At the same time, the neoliberal movement equates choice with liberty and freedom, in a sense echoing rights-based arguments. Milton Friedman's seminal Capitalism and Freedom (1962) outlines the reasons why full parental school choice is required in a free, capitalist society.

Many parts of the world have experienced considerable growth in the private school sector (Akaguri, 2014; Day Ashley et al., 2014; Härmä, 2008, 2013; Tooley \& Dixon, 2006; Tooley, 2009). Fully private schools that run entirely on user fees have been "mushrooming" in poorer parts of the world where government schools are not serving people well. In other instances, middle classes and elites use high-fee private schools, seeking to preserve and pass on their privilege to the next generation. In more economically developed countries with established welfare states or a commitment to government-funded education provision for all, a different wave of "school choice" is swelling. Here, taxpayer funds are directed towards charter schools, academies, and other types of publicprivate partnership schools, with varying results as described by Verger et al. in Chapter 7 of this volume.

In these differing contexts with different types of school choice mechanisms, two key aspects of human rights appear to be clashing - the liberty of a parent to choose their child's education on the one hand, and the right of a student to access free, quality education without discrimination or systemic barriers, on the other.

This chapter will explore the notion of school choice from a human rights law perspective, and with a practical, rather than a theoretical, approach, reviewing published evidence about countries' experiences with school choice in its various forms. In Section 2, the chapter begins by outlining the international law provisions on the right to education. Section 3 explores school choice as a concept and an issue. The extent of real choice in schooling is discussed, using cases of school choice as it has developed in various countries. Section 4 explores contexts injecting choice into a system by design, while Section 5 examines the more spontaneous, unplanned development of "choice". An analysis of contexts with little or no school choice and where serious and concerted public policy and investment have obviated the need for it offers a counterpoint to the supposed need for choice (Section 6). Discussion of the evidence, its ramifications, and conclusions comprise the final section (7). The chapter draws on secondary research available at the time of writing, from more developed countries and from others researching the Global South, and also draws heavily on the primary research of the author. 


\section{SCHOOL CHOICE AND THE INTERNATIONAL HUMAN RIGHT TO EDUCATION}

A considerable body of human rights law has built up over seven decades proclaiming, reinforcing, and embedding the notion that education is a human right, as presented in the Abidjan Principles. The starting point was the immediate post-war period, with the establishment of the United Nations and the adoption of the Universal Declaration of Human Rights in 1948. This declaration did not have the binding nature of a treaty or convention. However, in 1966, two key pieces of human rights law emerged: The International Covenant on Civil and Political Rights and The International Covenant on Economic, Social and Cultural Rights. These treaties elucidated the states' obligations to respect, protect, and fulfill the right to free, universal access to primary education as binding law. This was reaffirmed in the near universally-ratified human rights treaty, The 1989 Convention on the Rights of the Child. The 1960 UNESCO Convention Against Discrimination in Education fleshes out the right to education by stating that schooling must be non-discriminatory.

Governments have continued to reaffirm the commitment to education through major education gatherings that have proposed the achievement of Education for All at the end of a specified period of time: first in Jomtien in 1990 (The World Declaration on Education for All); next in Dakar in 2000 (The Dakar Framework for Action), and most recently in Incheon in 2015 (The Incheon Declaration and Framework for Action). All of these various efforts have continually reaffirmed that all children have the right to participate in education, irrespective of their personal or social circumstances.

The focus has traditionally been on governments acting as duty-bearers of the right to education by acting in the multiple roles of rights guarantor, funder, provider, and regulator. Yet government need not fulfill all of these roles. Government could fund provision of and access to schools supplied by non-government bodies. They could also fund an external organization that inspects and regulates schools, rather than acting as regulator. Alternatively, they could act to establish their own schools which they manage and fund. The key is simply that no child should be excluded for social, economic, or geographical reasons, or any other reason; treaties and frameworks for action have neither precluded nor promoted a key role for the private sector in any of these roles. With 
regard to "choice" specifically, the liberty to choose was envisaged as protection for people who might find themselves living under authoritarian rule, under a government that might use their own school system for purposes of coercion (Mowbray, Chapter 3, this volume; Zinigrad, Chapter 4, this volume). At the time they were developed these treaty provisions were not designed to support the types of market-driven school choice currently on offer.

School choice can be incompatible with the right to education when the choice of some parents leads to access to or quality in education being decreased for other children. This appears to be happening in the United States where charter schools ${ }^{2}$ have been promoted, ostensibly to provide better quality options for families whose children are attending local government schools that are labeled as failing, according to standardized test scores (Berliner \& Biddle, 1995). With funding following former government school pupils to new charter schools, the most disadvantaged and those that fail to gain access to a new school are left behind ${ }^{3}$ in schools that must struggle to meet the more challenging, and often more expensive, needs of the poorest and most marginalized students. Evidence on the socioeconomic background of government and charter school students shows that English language learners, low socioeconomic status students, and those with special needs attend public schools in much larger proportions than charter schools. However, as a direct result of school choice being exercised by some parents, these more challenging and demanding pupils must be taught with less funding and resources, and with less positive peer effects, than during previous eras (Abrams, 2016; Adamson and Darling-Hammond, 2016; Ravitch, 2013).

Currently, some governments are not providing education for all students, for example in urban informal settlements in the Global South where governments have shown reluctance to set up sufficient numbers of schools. ${ }^{4}$ In locations with both government and private schools, those

2 Charter schools are schools in the United States (called Academies in the United Kingdom) that are owned and run by non-government entities sometimes for profit and sometimes not for profit (always not-for-profit in the United Kingdom), but are funded by the government and do not charge user fees.

The opening of some charter schools has been significantly hyped, leading to them being over-subscribed. In such cases, lotteries are commonly used to determine who is admitted. Those "left behind" are the children whose parents are not able or motivated enough to seek admission to the school, or those who do not win a place through the lottery system.

See discussion below. 
who can pay school fees are abandoning government provision and foregoing government funding entirely by paying to send their children to private schools. This practice has been widespread amongst the middle and upper classes for a long time in many countries, but it has become increasingly common amongst the less well-off. The phenomenon of families who are not wealthy, paying for "no frills" private schooling already exists in richer countries, largely at religious schools (Walford, 2011), and appears to be growing. For instance, James Tooley is establishing low-fee private schools in north-east England (Economist, 2018; Turner, 2017), while Bob Luddy, a libertarian businessman, is establishing a similar chain in his home state of North Carolina in the United States (Epstein, 2017). In these situations, if all those who can pay end up attending private schools, the pressing need to find solutions for families "left behind" in under-resourced government schools receives less attention. In effect, school choice exercised by some parents negatively impinges on the right to a free, quality education for the poorest and most marginalized students by further stratifying educational provision.

Proponents of consumer choice within a market propose certain ways of averting inequity. First, targeted vouchers can support the poorest in making a specific school choice, although, to be meaningful, the voucher must cover enough, all, or sometimes more than the school costs. Charter schools (United States), academies (United Kingdom), or Free Schools (Sweden), funded by government directly rather than through an actual "voucher", also provide options for those who cannot pay. Despite the varying extents of government funding under various scenarios, evidence from developed and developing countries shows that "choice" usually bypasses the poorest as its exercise requires levels of awareness, time, organization, transportation, and motivation that financially-struggling parents often do not have (Burch, 2009; Carr-Hill \& Murtaza, 2010; Ravitch, 2013).

The liberty of people to set up schools, the liberty of parents to choose, and how these situations are (at times, and in certain conditions) unfortunately but unavoidably at odds with the wider right to good quality education for all, are all discussed at depth by Aubry and Dorsi (2016). While the original framers of the liberties in and to non-state education did not have the marketization of education in mind, a case can be made for the extension of this liberty to choose schools in the interests of children caught in difficult circumstances. However, this section of the chapter has mentioned "school choice" with a foregone conclusion that real, free school choices exist. The next section examines the concept of school 
choice, what it really means in practice, and whether or not parents are able to exercise real choice in education.

\section{SCHOOL CHOICE IN PRACTICE: WHAT DOES IT REALLY MEAN?}

This section discusses the basic elements of markets that need to be present for choice and competition to yield the purported benefits. It then discusses examples of locations where choice has developed as a result of policy and where it has developed in a more spontaneous, unplanned manner. It finishes by discussing the limits of school choice in light of the well-acknowledged inefficiencies of markets and governments.

\subsection{The Theory of School Choice}

Milton Friedman is the most famous and influential proponent of school choice and essentially the father of the neoliberal pro-market agenda that took root in the 1950s. In Capitalism and Freedom (1962), he set out proposals for full school choice, arguing that the government has no role to play in the provision of education. However, he posited that the imposition of a required minimum level of education as well as public funding to support this endeavor is justified by the positive "neighborhood effects" of schooling for the wider society. Friedman accepted the "public good" nature of education, through which the wider society benefits from all people being literate and educated to an (unspecified) extent.

Because poor parents would be unlikely to be able to pay the amounts required for the socially optimal minimum level of education for their children, Friedman suggested the provision of government funding through vouchers given to families. Parents would choose a school from a pool of government-approved institutions (strangely, indicating a regulatory role for government as well as the role of funder). Parents would be free to add to the voucher provided by government by "topping up" with their own income in order to access a perceived better quality of school.

School choice is suggested as a means of achieving ever greater quality and variety of education through a range of different providers, all serving various segments of a market in which providers compete for clients (parents and children). Competitive pressures are purported to lead to lower costs and therefore greater efficiency system wide. More recent decades have seen claims of markets fostering innovation in schools - implying innovation in the classroom, leading to higher learn- 
ing levels for students. The client, or the child and parents, can choose the option that suits them best, according to the aspects of education that they prioritize. Once in a school, families can continue to engage with school choice, changing schools when dissatisfied.

For these claimed benefits of the market to materialize, certain conditions need to be present:

- a range of interchangeable options from which clients can realistically choose (there must be no monopolistic provider or cartels);

- clear and objective information available to help parents to make informed decisions;

- parents should be able to make their choice freely with no onerous transaction costs.

Competition to achieve higher profits, or at least survival in the market would purportedly lead to higher quality education for children. In addition, neoliberal or neoconservative market proponents ascribe value to the very notion of the freedom to choose, in and of itself (Friedman, 1962). Sending a child to a neighborhood school is considered restrictive, even in cases where such schools are highly effective, as in Finland, and as they were in Sweden before school choice was introduced (Abrams, 2016).

"Pure" markets in the education sector do not exist in any country at the present time. All markets are subject to distortions and failures, and education markets are typical of this. The key distortion in education "pseudo-markets" is the existence of government-funded schools. These schools are usually not subject to market forces for their continued existence and operate under circumstances of limited or indirect/long route accountability. Yet this "distortion" is a consequence of the key market "failure", the inability of most people to pay the price of private education.

A yet more intractable failure is that of sparse and remote populations living in rural areas of many countries, and in areas with challenging terrain. These areas frequently have too few children to support competition between a range of providers; there may barely be enough children to support one school in a village. Friedman's response to this issue was that transportation is improving and fewer and fewer people are living in rural areas (Friedman, 1962). However, small communities still exist in all global contexts whose children need and deserve good schooling. Only schools existing entirely outside market logic (government schools 
and sometimes community schools) are financially able to serve poor and remote communities.

Government schooling systems also experience failures. State provision is meant to be of good quality, available to all residents, tuition fee-free (depending on the level, but almost certainly fee-free for "basic education", however defined in the context). However, in reality, schools in poorer countries are often under-funded, and so impose some level of fees (whether official or not - usually in poorer countries) which has the effect of excluding the very poorest. They also lack direct accountability to the families that they serve, with staff hired and paid through civil service staff structures (creating only indirect accountability). School leadership is often weak both in terms of management skills and the authority needed to run a school. These weaknesses lead to the predictable and well-documented results of teacher absenteeism, poor-quality instruction, and over-crowded and under-resourced classrooms - all of which have provided the push for many families to seek an alternative.

A crucial factor in the education space is that parents lack objective, reliable information on school quality in all types of schools. Parents often do what they can to assess the quality of the options available to them, often through discussions with other parents in the community (Srivastava, 2006), meaning that their conclusions are necessarily impressionistic or based on anecdote. Even in richer countries, obtaining real information on the quality of education is difficult. In many countries, information on schools' examination results are published, but with the stakes attached to these examinations growing, instances of cheating and teaching to the test have been documented, meaning that the examination results likely provide a poor reflection of actual teaching quality (Abrams, 2016; O'Neil, 2016; Ravitch, 2013). Furthermore, the focus on choice turns parents into consumers looking for the best deal for their children, rather than citizens interested in shared educational goals (Ravitch, 2013).

While the above discussion has set out the reasons why some degree of choice cannot quite qualify as true and free choice, the rest of this chapter will use the term "choice" to refer to situations where some degree of choice is available. The next sub-sections look at where choice has developed as the result of purposeful policy and then where it has developed by default, in an unplanned way. 


\subsection{School Choice as Policy}

Governments have instituted school choice policies, hoping to improve the quality of all schools through competition as a primary rationale. Richer countries such as the United States, Sweden, and Canada have willingly adopted school choice policies for a variety of reasons, while other countries have policies of privatization and choice essentially pushed on them - sometimes with the complicity of pro-market local partners. Examples of the latter include the voucher system in Chile, and, more recently, the possibility of complete system privatization in Liberia. School choice can be promoted in various ways, starting with allowing students to choose between government schools, instead of being automatically enrolled at their neighborhood school. But some choice proponents prefer the more direct means of providing schools with a per-pupil funding amount that follows the pupil to the school of the parents' choosing. This voucher-type approach can occur with various degrees of government regulation. For instance, disallowing all "top-up" payments or the charging of any other fees means that the different schools are truly available to all families (not taking into account issues of physical distance), irrespective of socioeconomic backgrounds. Governments can further stipulate that participating schools must take children on a first-come, first-served basis or through a lottery, in order to be as equitable as possible.

Another alternative to inject choice is through charter schools - privately owned and run schools that receive government funding, based on the numbers of pupils who enroll. In a funding sense, they are government schools, and have in many places replaced conventional government schools. In other places, they directly compete with government schools. For-profit corporations may or may not be allowed to operate schools and test-based accountability has often accompanied choice reforms as a means of judging the success or otherwise of the system (Burch, 2009). Both voucher and charter school cases have broadly not resulted in allowing the poorest to access private schools, with the poorest continuing to attend increasingly ghettoized government schools (Abrams 2016; Berliner and Biddle, 1995).

\subsection{Unplanned School Choice}

Where fee-paying private schools have appeared, often in ever-increasing numbers, "school choice" is said to have developed (Tooley, 2013). 
Private schools have existed for decades and centuries, often serving the middle and upper classes, but recent developments have seen private schools targeting the relatively poor springing up in great numbers in parts of India, Pakistan, Nigeria, Ghana, Kenya, Uganda, and Peru, amongst other countries. In Lagos, for example, the numbers of schools have grown at a fast pace, from a known 12,098 in 2011, to an estimated 18,000 - a growth of nearly 50 percent in three years (Härmä, 2011a; Rosales-Rogge et al., 2014). On the surface, considerable choice in private schools exists serving all socioeconomic levels of society. In 2015, 62 percent of primary school-going children were in private schools in Lagos (Nigeria National Population Commission and RTI International, 2015), meaning that only 38 percent are going to government schools. In Kampala, I estimated that 84 percent of all school-going children attend private schools (Härmä, 2016b, p. 4). However, to access these schools, parents must be able to pay termly fees, as well as registration and examination fees, and buy books and stationery, uniforms, and sometimes other costs that often make up around half of all education annual expenditures (Härmä \& Siddhu, 2017). In most places where these private schools have developed outside government planning or regulation, governments provide no support, financial or other, to families - they must find their own way in assessing (with no public information available), choosing and, crucially, paying for a private education.

\subsection{Limits to School Choice}

School choice will only generate the anticipated benefits when the choice is real, relevant and meaningful, i.e. when parents can choose an important aspect of their child's education, such as the pedagogical approaches used to teach them. If schools are not allowed to respond to diverse student populations, and to distinguish themselves from each other, choice is meaningless. (OECD, 2017, p.3)

The Organisation for Economic Co-operation and Development's (OECD) outlook on school choice shows that surface appearances of choice and competition are not enough; rather, certain elements need to be present before choice yields the anticipated benefits. This sub-section discusses the limits of school choice.

First, family choices are necessarily geographically bounded: most people do not want their children, especially very young children, traveling long distances to go to school, and many cannot afford the time or the cost involved in transporting their children to schools far from 
home. Even in large, densely-populated cities with many schools, choice is often geographically bounded because of distance or travel time. In remote, rural locations, choice is often confined to one's local village as children would have to travel long distances to the next location with a school. In rural Uttar Pradesh, India, with approximately 820 people per square kilometer, choice exists even in rural villages; however, in Kwara State in Nigeria, with just 80 people per square kilometer, there is virtually no school choice (Härmä, 2016a).

Education is also an ongoing "transaction" between the family and the school and it is difficult for parents to judge the quality of a school at the start. Rarely is there good, objective information on school quality, with test scores not providing a complete picture of school performance, being open to manipulation and cheating (Abrams, 2016; O'Neil, 2016; Ravitch, 2013). It also does not lend itself to frequent changing in the hopes of finding a better option; education is an area where, generally speaking, fewer changes proves better to avoid disruption to the child's education. In addition, depending on the nature of the local education "market", it might be the case that "choice" becomes "flipped" with popular schools being over-subscribed and therefore able to select the most able students. In addition, certain schools may seek to recruit higher achieving students from other schools in a bid to raise their own test scores, something that has happened in certain charter school-fueled choice environments in the United States, for example (Adamson \& Darling-Hammond, 2016). Alternatively, due to the costs (registration fee, new uniform, and textbooks), as well as concerns regarding continuity for the child, parents can feel "locked in" to their initial school choice (Härmä \& Siddhu, 2017).

Meaningful school choice only really exists where parents could, without detriment to their children, keep using the default school which in most systems should be the neighborhood government school. Diane Ravitch (2013) explores the notion of education as one of the few "commons" left in American society, and the notion is applicable to other countries also; a shared educational experience is widely seen to have benefits for nation building and social cohesion. For this reason, many argue that social benefits arise from children growing up and sharing a common schooling experience.

Yet there are instances where all children attending a common school may not be practical or desirable. Parents might choose not to use a school because they want a particular religious grounding for their child, or they may want a different type of pedagogy or philosophy, as 
with Steiner or Montessori schools. It is inevitable that not all families will live close enough to different types of schools to enable them to have such wide options. The limitations on choice are nearly inevitable; a truly dynamic market of choices for all is essentially unattainable. Even when choice does exist, competition does not automatically mean better quality education. The OECD has found that there is no country-level relationship between the quality of learning outcomes (as measured by 15 -year-olds' scores on the science examination as part of PISA [Programme for International Student Assessment] 2015) and the share of students enrolled in private schools. Among OECD countries, the correlation is almost zero, indicating that school choice does not necessarily lead to better quality education (OECD, 2017, p. 8).

\section{CONTEXTS WHERE CHOICE BECAME OFFICIAL POLICY}

This section looks at countries where official policies to create school choice were instituted. In Chile, a universal voucher scheme was instituted without the necessary safeguards to ensure that it would benefit disadvantaged families. In the Nordic countries, Sweden stands out with its universal school choice program, but this entailed safeguards to ensure no selective admissions policies and no additional fees could be charged to families.

\subsection{Chile}

Perhaps the most famous and one of the longest-term neoliberal experiments with school choice (as part of wider market reforms) has taken place in Chile since 1973 (Verger et al., 2016). Augusto Pinochet instituted a universal voucher system to allow full school choice, with most schools opting to participate in the voucher program and only the more selective schools opting to remain fully private. A 1993 addition to the scheme allowed schools to charge "top-up" fees, so that vouchers could be used in combination with family income to access more expensive schools. As a result, parents used the vouchers to move their children from government schools to private schools, while better-off families used the voucher to access even more expensive schools than they could afford previously. In addition, schools were allowed to be selective in their admissions while taking public money. By 2012, half of all school enrolments were in the private subsidized sector; 45 percent were in gov- 
ernment schools, while the remaining 5 percent were attending private, independent schools (Castro-Hidalgo \& Gomez-Alvarez, 2016).

At the same time teacher training was downgraded and salaries reduced (Verger et al., 2016). A nation-wide assessment system, known as SIMCE, was also instituted, further disincentivizing schools from accepting lower scoring pupils. Schools selected students because of the reputational damage that could ensue from the inclusion of poorly performing students whose examination results would appear as a reflection of school quality (Castro-Hidalgo \& Gomez-Alvarez, 2016).

With the poorest students left behind in government schools, coupled with a new teacher evaluation policy whose results were tied to those of the SIMCE, the message emerged that poor results in government schools were the result of ineffective teachers. However, the loss of all better-off peers to the private, subsidized sector meant that results were almost certain to be worse in government schools. Yet the reality is that government schools have proven more effective over a longer term at improving student learning than private independent or private, subsidized schools. This is particularly striking in light of the fact that private schools have been educating higher scoring pupils and those with greater social capital (Castro-Hidalgo \& Gomez-Alvarez, 2016).

The results of this more than four-decade experiment in school choice are much lower than average scores on international assessments and enormous socioeconomic stratification. The rich attend private independent schools, the middle and middle-to-high income pupils attend private, subsidized schools, while the low and low-to-middle income students attend government schools (OECD, 2012a). Chile's example underscores that public funding to private schools that does not specifically target disadvantaged students only leads to increasing stratification (OECD, $2012 b$ ), with the country having one of the most unequal education systems in the world.

\subsection{Sweden}

In 1991, Sweden got its first Conservative government for many years, and in 1992 it introduced a universal voucher system. The many new voucher-funded schools are known as Free Schools (Wiborg, 2013). This reform represented a radical departure from the welfare state approach to education that had been built up between 1945 and 1975, founded in the belief that equal educational opportunities were crucial in creating a fair and equal society (Wiborg, 2010; Åstrand, 2016). Sweden's com- 
prehensive schools had served all children from all types of families, with positive implications for social cohesion (Wiborg, 2010). Despite a return to power of the Social Democrats in 1994, the new system continued, and Sweden became "one of the world's most liberal public education systems" (Blomqvist, 2004, as cited in Wiborg, 2010, p. 10). There is no prohibition on for-profit providers and chains: Swedish private schools can be owned by stock companies, private companies, cooperatives, faith-based organizations, foundations, or almost any other type of organization (Åstrand, 2016). Key restrictions, however, include the prohibitions on charging any fees whatsoever, and on using selective admissions policies.

Although schools must teach the knowledge and skills outlined in the national curriculum and comply with the general objectives and values of the national system, they are granted a relatively high degree of freedom. The vision for the "market" was that a wide range of schools would develop, leading to more specialization in individual schools and overall greater variety as well as increased flexibility in school programs (Åstrand, 2016). Yet the reforms have not turned out as expected or predicted, with the majority of schools adopting a generalist, traditional approach, and mostly being operated by for-profit corporations. It was expected that parental cooperatives would spring up to establish schools (Wiborg, 2010), but this did not happen, seemingly indicating less interest in school choice on the part of parents than had been anticipated.

Most "innovation" is seen in school management and marketing, rather than in the classroom, with operators openly running their schools under McDonald's-style franchising arrangements and using marketing strategies that include attracting new pupils through offers of free computers and other gimmicks. The school chain Kunskapsskolan mimics the Ikea concept in providing the least possible support to its customers, in order to maximize profit. One school company owner in Sweden claims that "to run a school and to sell refrigerators are one and the same. It's about having your ear to the market and to understand where the needs are for our customers, the pupils" (Åstrand, 2016, p.73).

Sweden's private schools have experienced an unsurprising rise in investor interest. One case is illustrative of the pitfalls of such a liberal approach: one school company, Fourfront, grew at a fast pace in the early 2000s, and was then sold to JB Education, a company owned by the Danish venture capital firm Axcel. JB Education had experienced a high growth rate up to 2013, but then abruptly collapsed in bankruptcy, resulting in the schools being sold or closed (Åstrand, 2016, p. 85). This 
bankruptcy threw the educational continuity of 10,000 pupils into jeopardy (Orange, 2013).

It can be no great surprise that, with 70 percent of private schools run for-profit, the drive for lower costs and greater "efficiency" has led to private schools employing lower-qualified teachers, with lower proportions of teachers specifically qualified to teach the subjects that they teach. Teachers now do more non-teaching work, including marketing of the school to attract new clients. With much greater pressure on teachers, who feel less and less satisfied and valued in their work, has come grade inflation in schools, whereby teachers award students higher and higher grades in order to provide an image of student success (Abrams, 2016). Grade inflation has developed at the same time as Sweden's aforementioned declining results on international assessments and has been directly linked to the increase in market competition (Abrams, 2016). In addition, there has been an explosion in media and arts courses (Orange, 2011), while employers' organizations complain that secondary schools are not producing the types of graduates needed; students attend programs that are perhaps fun, but with less labor market relevance (Demsteader, 2013). Along with declining learning for pupils and declining working conditions for teachers has come greater inequity and stratification through school choice, with the better-off tending to gravitate towards certain schools (Abrams, 2016; Economist, 2013). The latest PISA round has found an ever-widening learning gap between low and high achievers (OECD, 2016).

\section{CONTEXTS WITH SCHOOL CHOICE EMERGING BY DEFAULT}

In many low and lower-middle income countries, a market in "low-fee private schools" has developed from the grassroots. Individuals set up small private schools as a result of perceived poor quality of education at government schools, or, in the case of many densely-populated urban informal settlements, no access to government schools at all. Low-fee private schools are now common in Lagos, Nairobi, Accra, Kampala, Lusaka, Delhi, Hyderabad, Lahore, and many other African and South Asian cities, but they are increasingly gaining a foothold in some rural areas as well, such as in Uttar Pradesh and several other Indian states. This "organic" development is lauded as the poor devising their own strategies to meet their own needs (Tooley, 2009). However, in reality, many parents' choices are severely curtailed through distance and 
affordability factors; lacking objective information on which to make quality assessments; taking place in an effectively unregulated context (despite regulations existing on paper); and essentially coerced due to the untenable state of affairs in the government system.

While parents believe they are buying a better quality education for their children, there is no clear evidence that private schools invariably do better than government schools (see Day Ashley et al., 2014, for an assessment of the available evidence regarding the quality of low-fee private schools which finds no clear verdict on this issue). However, even if no clear quality advantage could be proven, parents are nevertheless eager to pay for schools that are very often closer to home, with smaller class sizes, meaning that teachers know their children as individuals and keep tabs on them.

\subsection{The Rise of Low-fee Private Schooling in Sub-Saharan Africa and South Asia}

Governments in many cases have failed to keep pace with need, particularly in slums, where extending government services would be seen as extending legitimacy to what are deemed illegal settlements. In Lagos, authorities have no incentive to provide schools in areas that they wish to clear to make way for up-market development. Also, as all relatively affluent people and virtually all civil servants have abandoned the government school system, government schools receive reduced scrutiny on issues of quality and access. In Abuja, Nigeria's still relatively new capital, the Abuja Master Plan has been ignored in many cases, with plots of land specifically designated for government being granted to private schools and individuals for their own use instead (Härmä, 2019). In both Lagos and Abuja, along with many other similar contexts, government school capacity is vastly over-stretched. Additionally, they are too far from home for many families to access. In such circumstances, it is certainly the case that the option of a low-fee private school is wanted; however, it must be viewed for what it is, essentially school choice out of desperation - a coerced choice, rather than the positive exercise of a human right.

\subsection{The Problem of Affordability}

Despite the appearance in many contexts of many choices for families, real choice is limited by several factors, the biggest being the ability 
of families to pay school fees and other attendant costs. In rural Uttar Pradesh, it was found that 94 percent of parents interviewed preferred private schools, but only just over 40 percent of children were actually attending these schools. Those who preferred private schools but were not using them said their would-be choices were unobtainable due to inability to pay with their only actual options being government school or no school at all (Härmä, 2011b, p. 356). This finding is echoed in Lagos (Härmä \& Siddhu, 2017) and Kwara State, Nigeria (Härmä 2016a); as well as in Kampala (Härmä, 2016b). ${ }^{5}$ The costs of starting at a private school (registration fees as well as new books and uniforms, which come on top of the recurrent costs of tuition fees, examination fees, and others) curtail school choice and school switching.

\section{ACHIEVING GOOD QUALITY EDUCATION WITHOUT CHOICE (NOT A FOREGONE CONCLUSION)}

\subsection{Finland}

In the 1970s and 1980s, Finland was only an average achiever on the International Association for the Evaluation of Educational Outcomes' assessments of mathematics and science (Sahlberg, 2016); at the same time Finland was embedding and strengthening a fairly radical education reform that actually followed the lead of the Swedish system: from 1970 to 1979 the Finnish peruskoulu, or comprehensive school was launched and rolled out.

The reforms initiated the high-achieving Finnish school system that exists today, comprising three particular and significant characteristics. First, the equal opportunities principle insists that all students be offered the same education, which has required an emphasis on early identification of children with special needs and providing them with the necessary support. A second aspect of the new system has been to provide career guidance and counseling as part of the curriculum - ensuring emphasis on the connection between schooling and eventual working life. Third, a whole new philosophy of inclusive education had to be adopted, as this reform was not just a reorganization but an entirely new way of working,

2014 .

For a wider range of contexts and researchers, see Day Ashley et al., 
bringing together all types of children in the same classroom. This new philosophy recognized that all children can learn, given the right type of support, and that "schools should function as small-scale democracies, just as John Dewey had insisted decades before" (Sahlberg, 2015, p.30).

These greater demands on teachers and the education system led to the 1979 law on teacher education "emphasizing professional development and focusing on research-based teacher education" (Sahlberg, 2015, p.30), requiring that all teachers teaching primary school and above have a master's degree, and requiring that pre-primary teachers have a bachelor's degree. A spirit of collaboration pervades the teaching profession, with weekly full-afternoon meetings to jointly plan and develop curriculum. Schools within a municipality are encouraged to share materials and work together, and time within each teacher's working schedule is allocated for professional development (Sahlberg, 2016). Teachers are ever-developing and are supported to keep improving, in the spirit of a national joint venture. Instead of test-based accountability, Finland nurtures a trust-based responsibility that relies on teachers' and principals' professionalism and judgement; instead of school choice and competition, Finland focuses on equity of outcomes - and

because school learning is strongly influenced by children's family background and associated factors, equity of outcomes requires that schools are funded according to their real needs to cope with these inequalities. School choice often leads to segregation that increases inequity of outcomes. (Sahlberg, 2016, p.120)

Few Finnish parents feel that their neighborhood school is not the best school for their child, and the country continues to regulate private schools strictly. The establishment of private schools requires a decision of the Council of State, and the few private schools allowed are fully funded by the state and barred from charging any fees to parents. Around 75 private schools offer various religious approaches, languages of instruction, and particular pedagogical philosophies, such as the network of Steiner Schools. No school is allowed to use selective admission practices; private schools must admit pupils on the exact same basis as municipal schools (Sahlberg, 2015). It is safe to say that Finland is an environment of essentially no school choice, which has reaped benefits for social cohesion, equity in education outcomes, and keeping gaps between rich and poor at an absolute minimum. Finnish schools are a result of and reflect back the egalitarian ethos within the wider society. 


\subsection{Ontario, Canada}

Another example of an education system that has turned away from pro-market reforms is the province of Ontario. Canada has a federal governance system in which each province is separately responsible for its education system. Fullan and Rincon-Gallardo (2016) describe Ontario's recent education policy history as follows:

During the past two decades, Ontario has undergone an important transition from an aggressive neoliberal agenda ... to a more collaborative orientation based on financial stewardship, partnerships among stakeholders, and shared accountability for student success. The outcomes of these two approaches have been remarkably different: from stagnant performance, labour disruption, and public dissatisfaction with Ontario's public education system in the former approach, to improved performance, mostly vanished labour disruption, and improved morale and confidence in public education in the later approach. (p. 175)

In 1995, a Conservative was elected premier of the province on a platform of aggressive deficit reduction that led to severe cuts to the education budget, punitive policies regarding teachers, and encouragement of private school growth. What resulted was a decade of low morale and a worsening image of the public education system. This set the stage for the Liberal Party's victory in 2003, based on a platform that put renewal of the public education system near the top of the list of priorities. This proved an extremely popular move, and the party remained in power until June 2018.

Ontario provides another example of where a clear policy pursued relentlessly can build the strength of a system and lead to real and sustained improvement. The new approach to education repealed some of the support to private schools and adopted a focus on capacity building at all levels and instructional practices linked to good results; a spirit of partnership and learning from implementation both across and between schools and districts; and a spirit of high trust and partnership between school districts and unions. Research on the approach and dissemination of lessons as the reforms have progressed have been central to learning, adapting and improving, and imbedding better practices. Unlike the systemwide approach in Finland, Ontario chose to focus on a small number of ambitious goals such as improving literacy and numeracy; increasing high school graduation rates; closing achievement gaps; and increasing public confidence in education (Fullan \& Rincon-Gallardo, 2016). 
A key example of what the new approach meant in practice was that the Conservative government's program of teacher testing and recertification were cancelled in favor of a new teacher induction program aimed at supporting teachers to develop their skills. For elementary education, the efforts include "coaching, collaborative inquiry, online video and other supports related to instructional practices, networking schools and districts around effective practices, targeted interventions and various forms of collaborative professionalism" (Fullan \& Rincon-Gallardo, 2016, p. 181; emphasis added). "The provincial government developed a whole system improvement strategy based on partnership, capacity building, focus on results, and a relentless commitment to keep going deeper and deeper" (Fullan and Rincon-Gallardo, 2016, p. 180). Systems were built that allow for the identification of struggling schools and the implementation of the Ontario Focused Intervention Partnership, which uses non-punitive means to build capacity for improvement, rather than placing blame and eliminating staff.

The reforms have led to "a shared sense of purpose, capacity, clarity, and commitment among system leaders, and correspondingly among vast numbers of participants at all levels of the system" (Fullan \& Rincon-Gallardo, pp. 189-90). As a result, Ontario's student achievement has risen steadily since 2003, as have high school graduation rates. Perhaps most crucially for society as a whole, gaps in student achievement have reduced; for example, the differences between French or English learners and the rest of the student population have reduced by 83 percent; the gap for those with special needs has reduced by 8 percentage points. Along with this, the number of poorly performing schools has also decreased. As a result, public attitudes towards the education system, as measured through a dedicated survey, have improved from 43 percent affirming they are satisfied or very satisfied in 2002, to 65 percent in 2012 (Fullan \& Rincon-Gallardo, 2016).

\section{DISCUSSION AND CONCLUSIONS}

Ontario and Finland have pursued education improvement strategies that run almost entirely contrary to those promoted through the global education reform movement, or GERM, as described by Sahlberg (2016). The results have been overwhelmingly positive, famously-so in Finland; it should be noted that this took place as the result of committed policy and implementation work, not simply due to contextual factors. It is often argued that Finland is a small and ethnically quite homogenous country 
with a high income. However, Ontario is extremely diverse (including Toronto) and has a much larger population; Finland is equal in population size to several US states, and so could serve as a fitting model for state administrations. Indeed, several US states are following an approach closer to that of the northern neighbor, Ontario, than to other US states (Adamson \& Darling-Hammond, 2016, p. 159).

The discussion of school choice situations in poorer countries has shown that parents are often pushed into choosing a private option out of desperation and wanting the best for their children. But this is not a desirable situation and is only eroding the system overall: the poorest are left behind in over-crowded and increasingly ghettoized government schools. This type of unplanned school choice may be construed as benefiting government education systems by lessening the burden on them and leaving more resources for the poor, left behind. However, when all those with social capital and therefore "voice" abandon the system, the result appears to be ghettoization and lack of care or intimate knowledge on the part of the authorities, whose children also attend private schools.

The promotion of choice does not lead to the consistent upward pressure on quality anticipated, and often comes with negative unintended consequences, often to do with test-based accountability and other types of accountability measures. In the richer country cases, some charter/ voucher schools are performing well, but many are not, and the same is also true of low-fee private schools in poorer countries. These results are discussed in depth in the subsequent education-focused chapters (7-9) of this volume. What does appear to show through is that a strong emphasis on choice helps to turn citizens into consumers shopping for the best "deal" for their child, rather than community members supporting a school that belongs to the whole community. The notion that school choice is a freedom in and of itself worth valuing is, arguably, only true in a limited number of cases where wider liberties or rights for minorities are limited or threatened. If school choice is considered a human right, then it is, perversely, a right whose exercise often materially diminishes the rights and outcomes for less-fortunate children. Systems based on school choice such as Sweden and Chile have seen highly stratified and disappointing learning outcomes, along with increasing segregation. While the more motivated and able may reap benefits from school choice, this is the case only in a narrow sense, ignoring the "externalities" of having to live in an increasingly unequal society.

The original intention of the framers of the freedom of school choice and the liberty of individuals to establish private schools was to allow 
parents to stop their children from being conditioned by a tyrannical state and to allow parents with strong beliefs or linguistic needs to educate their children accordingly. This provision has been re-interpreted and co-opted by an entirely different cause, primarily in the last four decades: the promotion of marketization and the roll-back of the state which is a neoliberal project. The right to choose a school is equated with freedom itself - and by implication with fundamental human rights (Åstrand, 2016).

The example of Finland leads the way in showing how a system can provide true learning and support the human rights of children overall: a system that respects its teaching staff, relying on their professionalism and judgement; that provides more funding to reach the most difficult to educate; and that ensures that all children have an equal chance. In places where teachers do not have this level of skill and professional judgement, teachers' skills and knowledge need to be scaffolded in the short-term. Teachers should be educated, supported, and given proper induction in order to teach well. They also need to be responsible and accountable for the work that they do. School choice and related accountability mechanisms are not enough to bring about quality improvement, and increasing choice appears to be highly correlated with increasing segregation and stratification of school systems. Of note, this negative outcome seems to be common across richer and poorer countries; those with stronger and weaker regulatory systems; and contexts where choice was injected by design, and where it developed spontaneously, in a de facto manner. This indicates that the right of parents to choose requires careful balancing with the rights and interests of those who are not in a position to choose, and governments and societies need to consider the elements of society that they value most.

\section{REFERENCES}

Abrams, S. (2016). Education and the Commercial Mindset. Cambridge, MA: Harvard University Press.

Adamson, F., \& Darling-Hammond, L. (2016). The critical choice in American Education: Privatization or public investment? In F. Adamson, B. Åstrand, \& L. Darling-Hammond (Eds.), Global Education Reform: How Privatization and Public Investment Influence Education Outcomes (pp. 131-168). London: Routledge.

Akaguri, L. (2014). Fee-free public or low-fee private basic education in rural Ghana: How does the cost influence the choice of the poor? Compare: 
A Journal of Comparative and International Education, 44(2), 140-161. DOI: https://doi.org/10.1080/03057925.2013.796816

Åstrand, B. (2016). From citizens into consumers: The transformation of democratic ideals into school markets in Sweden. In F. Adamson, B. Åstrand, \& L. Darling-Hammond (Eds.), Global Education Reform: How Privatization and Public Investment Influence Education Outcomes (pp. 73-109). London: Routledge.

Aubry, S., \& Dorsi, D. (2016). Towards a human rights framework to advance the debate on the role of private actors in education. Oxford Review of Education, 42(5), 612-628. DOI: https://doi.org/10.1080/03054985.2016.1224301

Berliner, D., \& Biddle, B. (1995). The Manufactured Crisis: Myths, Fraud, and the Attack on America's Public Schools. New York: Basic Books.

Blomqvist, P. (2004). The choice revolution: Privatization of Swedish welfare services in the 1990s. Social Policy and Administration, 38(2), 139-155. DOI: https://doi.org/10.1111/j.1467-9515.2004.00382.x

Burch, P. (2009). Hidden Markets: The New Education Privatization. New York: Routledge.

Carr-Hill, R., \& Murtaza, A. (2010). Developing an Anti-Corruption Tool and Plan for the Punjab Education Foundation. London: Health and Education Advice and Resource Team.

Castro-Hidalgo, A., \& Gomez-Alvarez, L. (2016). Chile: A long-term neoliberal experiment and its impact on the quality and equity of education. In F. Adamson, B. Åstrand, \& L. Darling-Hammond (Eds.), Global Education Reform: How Privatization and Public Investment Influence Education Outcomes (pp. 16-49). London: Routledge.

Day Ashley, L., McLoughlin, C., Aslam, M., Engel, J., Wales, J., Rawal, S., Batley, R., Kingdon, G., Nicolai, S., \& Rose, P. (2014). The Role and Impact of Private Schools in Developing Countries. London: Department for International Development.

Demsteader, C. (2013, 16 January). Do Sweden's free schools make the grade? The Local. Retrieved from https://www.thelocal.se/20130116/45628

Economist. (2018). Can a $£ 52$-a-week private school work in the rich world? The Economist, 10 May.

Economist. (2013). Fixing Sweden's schools. The Economist, 2 November.

Epstein, J. (2017). A libertarian builds low-cost private schools for the masses. [Reason.com: Free Minds And Free Markets]. Retrieved from http://reason .com/reasontv/2017/01/23/thales-academy-north-carolina-bob-luddy

Friedman, M. (1962). Capitalism and Freedom. Chicago: University of Chicago Press.

Fullan, M., \& Rincon-Gallardo, S. (2016). Developing high-quality public education in Canada: The case of Ontario. In F. Adamson, B. Åstrand, \& L. Darling-Hammond (Eds.), Global Education Reform: How Privatization and Public Investment Influence Education Outcomes (pp. 169-193). London: Routledge.

Härmä, J. (2019). Ensuring quality education? Low-fee private schools and government regulation in three sub-Saharan African capitals. International 
Journal of Educational Development, 66, 139-146. DOI: https://doi.org/10 $.1016 /$ j.ijedudev.2018.10.007

Härmä, J. (2016a). School choice in rural Nigeria? The limits of low-fee private schooling in Kwara State. Comparative Education, 52(2), 246-266. DOI: https://doi.org/10.1080/03050068.2016.1142737

Härmä, J. (2016b). Low Fee Private Schools in Low-Income Districts of Kampala, Uganda. Chicago: Capital Plus Exchange. Retrieved from http://capplus.org/ files/2017/04/Kampala-Private-Schools-Market-Study-2017-03-24.pdf

Härmä, J. (2013). Access or quality? Why do families living in slums choose low-cost private schools in Lagos, Nigeria? Oxford Review of Education, 39(4), 548-566. DOI: https://doi.org/10.1080/03054985.2013.825984

Härmä, J. (2011a). Lagos Private School Census 2010/2011 Report (Report LG501). Abuja: DfID-ESSPIN.

Härmä, J. (2011b). Low cost private schooling in India: Is it pro-poor and equitable? International Journal of Educational Development, 31(4), 350-356. DOI: https://doi.org/10.1016/j.ijedudev.2011.01.003

Härmä, J. C. (2008). Are Low-fee Private Primary Schools in Uttar Pradesh, India, Serving the Needs of the Poor? (Doctoral dissertation, University of Sussex). Retrieved from https://ethos.bl.uk/OrderDetails.do?uin=uk.bl.ethos .494941

Härmä, J., \& Siddhu, G. (2017). Why Do Parents Default? Parental School Choice and Affordability in a Time of Recession. Lagos: DFID-DEEPEN.

Nigeria National Population Commission \& RTI International. (2015). DHS EdData Survey, Lagos Report. Abuja: National Population Commission.

OECD. (2017). School Choice and School Vouchers: An OECD Perspective. Paris: OECD.

OECD. (2016). Programme for International Student Assessment (PISA) Results from PISA 2015 Sweden Country Note. Paris: OECD.

OECD. (2012a). Equity and Quality in Education: Supporting Disadvantaged Students and Schools. Paris: OECD.

OECD. (2012b). Public and Private Schools: How Management and Funding Relate to their Socio-economic Profile. Paris: OECD.

O'Neil, C. (2016). Weapons of Math Destruction. London: Penguin Books.

Orange, R. (2013). Schools - confusion reigns after collapse of free-school chain. Times Education Supplement, 28 June 2013. Retrieved from http://www.tes.co .uk/article.aspx?storycode $=6341728$

Orange, R. (2011). Doubts grow over the success of Sweden's Free Schools experiment. The Guardian, 10 September 2011. Retrieved from http://www .theguardian.com/world/2011/sep/10/sweden-free-schools-experiment

Ravitch, D. (2013). Reign of Error: The Hoax of the Privatization Movement and the Danger to America's Public Schools. New York: Vintage Books.

Rosales-Rogge, G., Kadiri, D., \& Hinton, P. (2014). Schools as a Sustainable Business Survey (Report number FN-2014-01). Lagos: DFID-DEEPEN.

Sahlberg, P. (2016). The Finnish paradox: Equitable public education within a competitive market economy. In F. Adamson, B. Åstrand, \& L. Darling-Hammond (Eds.), Global Education Reform: How Privatization and Public Investment Influence Education Outcomes (pp. 110-130). London: Routledge. 
Sahlberg, P. (2015). Finnish Lessons 2.0. New York: Teachers College Press.

Srivastava, P. (2006). Private schooling and mental models about girls' schooling in India. Compare: A Journal of Comparative and International Education, 36(4), 497-514. DOI: https://doi.org/10.1080/03057920601024958

Tooley, J. (2013). Challenging educational injustice: "Grassroots" privatization in South Asia and sub-Saharan Africa. Oxford Review of Education, 39(4), 446-463. DOI: https://doi.org/10.1080/03054985.2013.820466

Tooley, J. (2009). The Beautiful Tree. Washington, DC: The Cato Institute.

Tooley, J., \& Dixon, P. (2006). "De facto" privatization of education and the poor: Implications of a study from sub-Saharan Africa and India. Compare: A Journal of Comparative and International Education, 36(4), 443-462. DOI: https://doi.org/10.1080/03057920601024891

Turner, C. (2017). Britain's first cut-price private school will charge parents just $£ 52$ per week. The Telegraph, 21 February.

Verger, A., Fontdevila, C., \& Zancajo, A. (2016). The Privatization of Education: A Political Economy of Global Education Reform. New York: Teachers College Press.

Walford, G. (2011). Low-fee private schools in England and in less economically developed countries. What can we learn from a comparison? Compare: A Journal of Comparative and International Education, 41(3), 401-413. DOI: https://doi.org/10.1080/03057925.2010.542033

Wiborg, S. (2013). Neo-liberalism and universal state education: The cases of Denmark, Norway, and Sweden, 1980-2011. Comparative Education, 49(4), 407-423. DOI: https://doi.org/10.1080/03050068.2012.700436

Wiborg, S. (2010). Swedish Free Schools: Do They Work? (Centre for Learning and Life Chances in Knowledge Economies and Societies (LLAKES) Research Paper, 18). London: Institute of Education. Retrieved from http://www.llakes .org $\backslash$ 